Article

\title{
Click to Buy: The Impact of Retail Credit on Over-Consumption in the Online Environment
}

\author{
Lauren Ah Fook and Lisa McNeill *(D) \\ Department of Marketing, Otago Business School, University of Otago, Dunedin 9016, New Zealand; \\ lauren.ahfook@postgrad.otago.ac.nz \\ * Correspondence: lisa.mcneill@otago.ac.nz; Tel.: +64-3479-5758
}

Received: 18 August 2020; Accepted: 2 September 2020; Published: 7 September 2020

check for updates

\begin{abstract}
There is growing concern that worldwide cultures of consumption have had detrimental consequences for individual wellbeing and sustainability of the environment. The term "overconsumption" exemplifies the tension between mutually beneficial producer-consumer exchange and the damaging effects of excess. In search of a pathway toward reducing overconsumption practise, sustainability literature is often interested in better understanding not only why overconsumption occurs, but what facilitates it in particular consumer markets. Young adults are one group of consumers where transitioning identities and lifestyles see impulsive consumption of goods that are often termed "non-essential", such as fashion and apparel products. This study explores the impact of a set of impulse enabling financial tools (buy-now-pay-later (BNPL) credit schemes) on impulse buying tendency in an online fashion shopping context, for young adult female consumers. The paper contributes a consumer perspective on the impact of BNPL on unsustainable consumption behaviour in the online retail setting, which the literature currently lacks, by considering consumers' impulse buying tendencies in such a setting. Findings demonstrate that BNPL users have a higher online impulse buying tendency than those who do not use BNPL, and a clear link is identified between online impulse buying tendency and sales conversion tool sensitivity, thus promoting overconsumption in this setting.
\end{abstract}

Keywords: overconsumption; buy-now-pay-later; impulse buying tendency; online retailing; conversion tools; consumer credit; unsustainable consumer behaviour

\section{Introduction}

Currently, it is estimated that one quarter of all global emissions stem from the manufacture and consumption of retail goods such as fashion products, electronics and other consumables [1]. Although consumers are increasingly well educated regarding the damaging impact of a number of consumption behaviours, overconsumption is still common within certain product markets [2]. The current culture of retail consumption seen in affluent, Western economies continues to threaten both the environment and the societies within which goods are produced [3]. In order to address this significant sustainability issue, it is essential that overconsumption is specifically addressed within industrialised nations [4]. Overconsumption has detrimental consequences for individual wellbeing and sustainability of the environment [5], and exemplifies the tension between mutually beneficial, voluntary exchange, and the damaging effects of excess waste [6]. This study addresses the problem within one group of overconsumers, young adult females, by examining their online impulse buying behaviour, and the systems that promote excess consumption in the online retail setting. 


\subsection{Impulse Buying and Overconsumption in Online Retailing}

Impulse buying is considered a departure from regular shopping practice, yet it is said to account for between $30 \%$ and $50 \%$ of self-reported purchases [7], and $40 \%$ of all online expenditure [8,9]. It is estimated that, in Western households, consumers spend approximately USD 5400 per year on impulse purchases of retail items including fashion, food and household products [10]. Despite this, consumers themselves are thought to severely underestimate their actual impulse purchasing [11]. This non-acknowledgement of the extent of their unplanned shopping is likely due to the negative social implications of such behaviour [7,12], with this lack of mindfulness of the part of a consumer, in regard to their personal shopping habits, contributing to the extent of the problem [4].

In sustainability terms, one of the most significant issues in addressing overconsumption is the attitude-behaviour gap evident amongst modern consumers, who are well educated regarding sustainability principles [2]. Consumers who profess motivation toward more conscious consumption choices often behave entirely differently at the point of purchase, with drivers such as lifestyle or demographics promoting behavioural intention discrepancies [13]. Studies of sustainable consumption have tended to focus on what promotes or constrains sustainability intention [14,15], or on motivators toward low consumption [16]. Fewer studies have examined singular aspects of the purchase decision process and how this interacts with individual consumption psychology, such as the role of consumption enabling tools in promoting overconsumption.

Consumption is an accepted fundamental part of life, where basic needs initiate the acquisition of products such as clothing and food. However, socially driven consumption behaviours, supported by materialistic social values, have led to overconsumption in almost all retail categories [17]. A drive toward materialism, when combined with a lack of consumption self-control, thus increases the likelihood of overconsumption in any category a consumer engages with [4]. When seeking to understand the links between impulse purchasing and overconsumption, the literature highlights a disconnect between psychology theory, which posits that impulsiveness is primarily driven by internal prompts [18-21] and marketing theory which focuses on external drivers of such behaviour, particularly where the online environment is concerned [22]. This tension underscores the current gap in existing knowledge regarding consumer impulsivity in the online setting, where a consumer's natural impulsiveness in material acquisition must be considered separate from their response to various market stimulation tools.

The online retail environment has not only changed dramatically in the past decade, but also expanded, as users are able to access the internet through an increasing number of devices [23-25]. With increased ownership, usage and portability of devices [25], people are spending more of their time online, and this is reflected in the proliferation of e-commerce and mobile-commerce retail platforms available to consumers [26]. Online shopping has become increasingly normalised in most markets [27], and, as a consequence, retail websites are perceived by consumers as increasingly reliable and trustworthy [28]. More resources than ever have been directed toward making online retail channels evermore functional to compete with, complement, or at times replace entirely the physical store [29]. In this new and rapidly evolving consumer context, the speed, 24/7 accessibility and comparative ease of browsing items makes online retail channels particularly conducive to impulse buying [22,27].

Impulse buying, as defined by Rook [12], describes an instance of immediate purchase whereby "a consumer experiences a sudden, often powerful and persistent urge to buy" (p. 191). Tendency toward impulse buying is therefore a measure of the degree to which any individual might make "unintended, immediate or spontaneous and unreflective purchases" [30], p. 506. Extant theory regards impulse buying tendency (IBT) as made up of a two-part interaction of state (situational) and trait (individual) behavioural moderators, suggesting a decision-processing aspect that balances pleasure seeking and self-regulation [31-33]. On this basis, individuals with higher IBT are more likely to make an impulsive purchase, and so are more likely to be susceptible to external market stimuli. 
Impulsive consumption behaviour has received considerable attention in retailing research. Understanding the intersection between internal psychological factors unique to the individual with market facing external stimuli has formed a significant portion of this body of work [34]. The overarching viewpoint of scholars of impulsive buying theory is that impulsivity in the retail consumption setting can be triggered and influenced [35]. Where a consumer may have particular individual traits that categorise them as highly impulsive in their consumption decision-making, studies have confirmed the importance of situation-specific resource availability (e.g., time and money) for this impulsivity to be enacted in the retail setting [36]. More recent research has thus been focused on understanding how impulse buying trait determinants interact with purchase motivation, resources and marketing stimuli $[34,37]$.

\subsection{Purchase Stimuli and Overconsumption in the Online Retail Setting}

Conversion tools are marketing stimuli that specifically aim to convert browsing visitors into purchasing customers [38]. While there has been considerable study of website attributes (e.g., colour, layout, font, sound) and how these impact consumer behaviour in the online setting [39], few studies have specifically examined conversion-type tools within a website that alter the conditions of a regular online sale. These tools include price promotions, but are also extended to value added offers of free shipping or free returns. As well as value enhancing offers, websites are more and more often employing instant decision-making facilitators such as low stock indicators, or targeted customer "chat" functions. Online marketing stimuli such as this is said to allow buyers to be less risk averse, and more likely to buy impulsively [40]. The very nature of these conversion tools, specific to the online environment, can reasonably be assumed to enhance or encourage impulse buying behaviour, as they directly mimic many of the environmental factors that are known to be persuasive in physical in-store shopping, such as perceived time pressure [41], instant price promotions [42], or reminders of past behaviour [43].

Impulse buying has been identified as a hedonic behaviour, driven by feelings of pleasure and excitement [37]. Verplanken and Herabadi [20] identified that this tendency is grounded in both cognitive and affective elements (cognitive being concerned with the processing and evaluation of circumstances, and affective being concerned with the emotional responses implicated in the process). Coley and Burgess [44] make this distinction, breaking cognitive elements into separate traits of unplanned buying and short-cognitive deliberation, and affective elements into the irresistible urge to buy, positive buying emotion, and mood management. Each of these elements are consistent with original definitions of impulse buying by Rook and Fisher [45], and Beatty and Ferrell [41], and exemplify the importance of both the cognitive and affective pathways in understanding impulsive purchasing.

The online setting supports the hedonic experience of consumption by removing some of the usual in-store behavioural restraint signals (such as the absence of high spending cues) [46]. It is suggested that over $60 \%$ of purchases are made impulsively, and that online buyers are more impulsive than those in-store [47]. It is known that website experience, convenience and "web atmospherics" (including graphics, search engine and one-click purchasing) are likely to promote impulse purchasing beyond that normally seen in a bricks-and-mortar retail setting $[9,48]$. What is less certain is how the impulse favourable environment of the online store is enhanced through the use of targeted marketing stimuli that push already sensitive consumers toward an immediate purchase, and recent studies have called for more investigation of individual marketing stimuli in this context [34]. Therefore, to examine this aspect of online purchasing, it is hypothesised that a consumer's tendency toward impulsivity will correlate to their sensitivity to such marketing stimuli:

Hypothesis 1 (H1). Impulse buying tendency (IBT) will significantly predict conversion tool sensitivity in the online setting. 
Alongside of marketing stimuli found in the online stetting, the growth of consumer use of credit cards and digital currency forms has promoted online purchasing [49]. The use of a credit card is said to lower perceived cost of purchases, thus accelerating impulsive decision making in the retail environment [50]. Access to credit has been previously shown to make people buy more, with the greater the number of credit cards owned, the higher purchase frequency observed [51], and the greater the overall purchase spend [52]. This effect is most prominently seen within apparel purchase (one of the highest volume categories of online retail sales), where credit card use is strongly associated with consumer impulse buying [53]. Where we know that credit card use results in impulse purchasing online [42], and that credit-based buying facilitates the instant gratification a consumer is seeking via such purchases [54], the impact of the newest generation of retail consumer credit products is still unknown.

The current "generation of borrowers" are exposed to increasing waves of aggressive financial product marketing, revolving credit and increased access to unsecured finance [55]. Buy-now-pay-later (BNPL) programmes come as a more recent addition to the consumer retail environment, directly competing with more traditional lending propositions [56]. A key difference between BNPL platforms and bank credit is that banks are charged with a social responsibility to only offer what a borrower can repay. BNPL platforms do not share this obligation [57], as they are often unregulated or ungoverned by traditional lending criteria. What results is an increased availability of funds to consumers who willingly enter financial agreements with few criteria and fewer safeguards, but may be perceived as less binding due to their separation from traditional credit companies. BNPL schemes share features of both traditional lay-by, credit cards and overdraft credit, requiring payment in regular instalments, and allowing consumers immediate access to goods. However, BNPL programmes could be assumed to be more attractive to consumers as they are sold as interest-free and fee-free, with goods not costing the consumer more than the original purchase price (if all instalments are paid on time). In this fashion, BNPL products can be theorised to promote impulse buying, both at the cognitive and affective levels:

Hypothesis 2 (H2). Use of BNPL platforms will significantly positively predict impulse buying tendency in the online setting;

Hypothesis 2a (H2a). BNPL users will be significantly more cognitively impulsive than non-users;

Hypothesis $\mathbf{2 b} \mathbf{( H 2 b ) . ~ B N P L ~ u s e r s ~ w i l l ~ b e ~ s i g n i f i c a n t l y ~ m o r e ~ a f f e c t i v e l y ~ i m p u l s i v e ~ t h a n ~ n o n - u s e r s ; ~}$

Hypothesis 3 (H3). Prior BNPL use will positively predict future intention to use BNPL in the online setting.

\section{Methodology}

This project sought to investigate the relationship between impulse buying behaviour in the online setting and buy-now-pay-later (BNPL) services, among young adult female consumers (18 to 25 years). The study used a survey approach to measure an individual's impulse buying tendency (IBT) in comparison with their use of BNPL services. The aim of the survey was to investigate the individual tendency of respondents to act impulsively in their online shopping experiences, and its correlation with the use of delayed payment options. A young adult consumer sample was selected as this segment are said to have a tendency to accumulate debt, with some noting that this group is the target demographic for finance schemes such as BNPL [58]. Further, young adult consumers are often in a transitional financial period of their life [59] and prone to non-essential consumption [60]. Females are noted to be more prone to impulsive buying [61], and a homogenous sample aids in interpretation of results, hence criteria for inclusion in the study were that respondents were female, aged between 18 and 25 years of age, and shopped online. A survey method was consistent with previous impulse buying tendency studies, e.g., [20,43,45,62]. 


\subsection{Instrument Design}

The survey was divided into three sections, the first of which measured impulse buying tendency (IBT) in the online setting, the second measured sensitivity to sales conversion tools commonly employed by online sites, and the third asked general questions about finance and credit usage in online transactions. To measure participants IBT score, the 20-item impulse buying tendency scale developed by Verplanken and Herabadi [20] was modified for an online setting. Responses were reported along a 7-point agree-disagree Likert scale, with items split into cognitive and affective aspects of impulse buying behaviour (allowing specific cognitive-online impulse buying tendency (OIBT) and affective-OIBT scores to be generated).

To measure sensitivity to common online sales conversion tools, the survey used visual representations of a live end-of-sale countdown widget, a "low stock" and " 1 item left" widget, and offers of free shipping and free returns. For each of the five stimuli, participants were given a scenario whereby they liked an item, but were unsure of whether to complete the purchase. A further, additional scenario was given whereby participants were told they had abandoned the purchase, but were later were sent email offers from the retailer. The two visual stimuli assessed in this scenario were a "saved cart" reminder and a flash discount offer. For both scenarios, participants reported their post-stimuli likelihood of purchase along a Likert scale of: (1) would definitely not buy; (2) probably not; (3) possibly; (4) probably; (5) very probably; or (6) definitely. A conversion sensitivity score was calculated for each participant by averaging their responses across the seven conversion stimuli.

Lastly, participants in the survey were asked questions regarding their discretionary income, if they owned and used a credit card, had previously used BNPL services or had an overdraft-enabled bank account. Additional questions were asked about the frequency of use of credit cards and BNPL services, with responses reported along a 7-point Likert scale consisting of: (1) I have never used X; (2) I use X yearly; (3) every 4-6 months; (4) every 2-3 months; (5) monthly; (6) weekly; or (7) more than once a week.

\subsection{Sample and Procedure}

Useable, complete responses were collected from 109 individual females aged between 18 and 25 years. The survey was advertised via social media, in a convenience sampling approach, asking for women in this age group who shopped online to participate (incentivised by a prize draw for a NZD 50 cash card). The sample size is consistent with Verplanken and Herabadi [20], allowing the same data analysis method as the original study to be used. For consistency between this study, and that from which the IBT scale was drawn, multiple regression was used to test hypotheses. The size of the final sample led us to believe that a regression approach would also be more robust than an SEM approach, and offer better outcomes for managerial implications to be drawn. Our reasoning being that, while some evidence exists that simple SEM models could be tested meaningfully with small samples, e.g., $[63,64]$, many other researchers propose that a much larger sample size than might be used for regression is required, e.g., $[65,66]$. Simulation studies show that, even with normally distributed indicator variables and no missing data, a reasonable sample size for a simple CFA model is around $n=150$, e.g., [67]. As a rule of thumb, for SEM and related models with relatively high R-squared statistics for some or most of the path loadings in the final path model, smaller sample sizes can be used, with caution, if they meet the requirements suggested by Gerbing and Anderson [68] (between 5 and 10 times the number of parameters estimated by a given SEM, which is a little less than $5 \times(($ number of measurement items $) \times 2+(($ number of factors $) \times($ number of factors -1$)) / 2))$. Our sample does not meet this requirement, thus, supporting the standard regression approach. 


\section{Results}

\subsection{Validating the Online Impulse Buying Tendency Scale}

The 20 items which measured online impulse buying tendency were subjected to a principal component analysis. The Kaiser-Meyer-Olkin (KMO) measure of sampling adequacy was 0.847, above the suggested threshold of 0.6. The first six eigenvalues suggested one dominant factor, but the shape of the scree plot gave reason to investigate the two-factor solution also. The direct oblimin rotation method was used. The first factor accounted for $36 \%$ of the variance, and the second accounted for an additional $8.95 \%$ of the variance. Similar to the Verplanken and Herabadi [20] study, the first factor predominantly involved items associated with the cognitive aspects of impulse buying, and the second factor involved predominantly affective aspects. Items 2 and 6, which were originally associated with the cognitive factor, loaded higher on the affective factor in the present study. Additionally, Items 12, 18 and 19 loaded highest on the cognitive factor, despite being classified as affective items in the original study. When the 11 new cognitive items and nine new affective items were averaged (Cronbach alpha values of 0.828 and 0.796 , respectively), they were significantly correlated, $r=0.811$, $p=0.00$. The Cronbach alpha for the full 20-item scale was 0.897 (threshold for internal consistency is $>0.7$ for social sciences).

To assess whether the psychometric integrity of the scale was maintained through item modifications, the factor loadings from the original study (see [20], Table 1, p. S76) were taken and compared with the equivalent factor loadings of the new scale. The factor structures of both were fairly similar in spite of minor differences in loading size and item distribution, with factors seemingly representing the same constructs of cognitive (Factor 1) and affective impulsive tendencies (Factor 2). For a more rigorous comparison, a Tucker's coefficient of congruence was calculated (using Wuensch [69]), consistent with the original authors' scale comparisons (see [20], p. S78-S79). The 20-item scales returned a congruence coefficient of 0.97 , and first and second factors 0.84 and 0.85 , respectively.

Table 1. Hypotheses Support.

\begin{tabular}{cc}
\hline Hypotheses & Outcome \\
\hline Hypothesis 1 (H1) & Supported \\
Hypothesis 2 $(\mathrm{H} 2)$ & Supported \\
Hypothesis 2a (H2a) & Supported \\
Hypothesis 2b (H2b) & Supported \\
Hypothesis 3 (H3) & Supported \\
\hline
\end{tabular}

Based on the initial factor loadings, Item 14 was excluded from the final scale because neither factors (0.051 and 0.231, respectively) loaded above the recommended cut-off of 0.3. Item 19 loaded highest on the first factor, as shown in Table 2 but additionally had a loading above 0.3 for the second factor. Usually, cross-loaded items such as this would also be removed from the final scale as they cannot be said to effectively measure the factor they are associated with. However, a similar cross-loaded item resulted in the original study and the authors chose to keep it as part of their final scale. To remain consistent with the original scale development process, it was also included here. Principal components analysis with direct oblimin rotation was conducted on the revised, 19-item OIBT scale. This did not alter the previous distribution of items between factors (11 cognitive items and 8 affective items), and all loadings were above 0.3 (see Appendix A). 
Table 2. Factor loadings for single factor and two-factor solutions (sorted by size).

\begin{tabular}{|c|c|c|c|c|}
\hline \multicolumn{5}{|c|}{ Cognitive items (factor 1 highest loading) } \\
\hline 1 & $\begin{array}{l}\text { I usually think carefully before I buy something } \\
\text { from an online store * }\end{array}$ & 0.739 & 0.885 & -0.078 \\
\hline 8 & $\begin{array}{l}\text { Before I make an online order, I always carefully } \\
\text { consider whether I need it* }\end{array}$ & 0.675 & 0.834 & -0.103 \\
\hline 10 & I often buy things online without thinking & 0.785 & 0.744 & 0.155 \\
\hline 4 & $\begin{array}{l}\text { Most of my online purchases are planned } \\
\text { in advance* }\end{array}$ & 0.687 & 0.742 & 0.025 \\
\hline 3 & $\begin{array}{l}\text { If I buy something online, I usually do } \\
\text { it spontaneously }\end{array}$ & 0.733 & 0.726 & 0.108 \\
\hline 9 & I'm used to online shopping 'on the spot' & 0.754 & 0.617 & 0.268 \\
\hline 12 & $\begin{array}{l}\text { I sometimes cannot suppress the feeling of } \\
\text { wanting to buy something and just make an } \\
\text { online purchase }\end{array}$ & 0.668 & $0.522 * *$ & $0.268^{* *}$ \\
\hline 19 & I am a bit reckless in buying things online & 0.769 & $0.500 * *$ & $0.431^{* *}$ \\
\hline 18 & $\begin{array}{l}\text { If I see something new on a website, I want to } \\
\text { buy it }\end{array}$ & 0.556 & $0.445^{* *}$ & $0.210 * *$ \\
\hline 7 & $\begin{array}{l}\text { I like to compare different brands before I make } \\
\text { an online purchase* }\end{array}$ & 0.248 & 0.433 & -0.193 \\
\hline 5 & I only buy things online that I really need * & 0.632 & 0.414 & 0.351 \\
\hline \multicolumn{5}{|c|}{ Affective items (factor 2 highest loading) } \\
\hline 17 & I find it difficult to pass up a good online deal & 0.559 & -0.058 & 0.828 \\
\hline 13 & $\begin{array}{l}\text { I sometimes feel guilty after having bought } \\
\text { something online }\end{array}$ & 0.424 & -0.090 & 0.684 \\
\hline 16 & $\begin{array}{l}\text { I always see something I want when I browse } \\
\text { online stores }\end{array}$ & 0.261 & -0.184 & 0.578 \\
\hline 20 & $\begin{array}{l}\text { I sometimes make an online order because I like } \\
\text { buying things, rather than because I need them }\end{array}$ & 0.703 & 0.360 & 0.513 \\
\hline 15 & $\begin{array}{l}\text { I can become very excited if I see something is } \\
\text { available online that I would like to buy }\end{array}$ & 0.460 & 0.107 & 0.493 \\
\hline 2 & $\begin{array}{l}\text { I usually only buy things that I initially intended } \\
\text { to buy from a website* }\end{array}$ & 0.434 & $0.094^{* *}$ & $0.473^{* *}$ \\
\hline 6 & It is not my style to just buy things online * & 0.557 & $0.236^{* *}$ & $0.466^{* *}$ \\
\hline \multirow[t]{2}{*}{11} & $\begin{array}{l}\text { It is a struggle to leave nice items in my cart } \\
\text { when I am browsing online }\end{array}$ & 0.621 & 0.333 & 0.435 \\
\hline & Items excluded from the final scale & & & \\
\hline 14 & $\begin{array}{l}\text { I'm not the kind of person who 'falls in love at } \\
\text { first sight' with things I see online * }\end{array}$ & 0.217 & 0.051 & 0.231 \\
\hline
\end{tabular}

Because the components returned a different distribution of items from the original study, it was necessary to analyse the newly formed factors to ensure the factor sentiments remained the same. Overall, Factor 1 items reflected cognitive components of impulse buying, and Factor 2 reflected affective components. The items "I sometimes cannot suppress the feeling of wanting to buy something and just make an online purchase", "I am a bit reckless in buying things online" and "If I see something new on a website, I want to buy it" were original affective-coded items that loaded highest with the cognitive factor in the replicated study. It would appear that these items do also uphold the cognitive 
elements of impulse buying, because all three of them connote the speed and lack of deliberation associated with cognitive impulsivity. For instance, the particular phrasing of "and just make a purchase" implies an instant behavioural response following the urge to buy; "recklessness" also implies an absence of the thought; and presenting the two corollaries of the third item (18) in such succession suggests immediacy.

\subsection{Sample Descriptives}

The mean of the online impulse buying tendency (OITB) scale across the sample was 3.77 $(\mathrm{sd}=0.96)$. The mean cognitive- and affective-OITB scores were $3.36(\mathrm{sd}=1.10)$ and $4.33(\mathrm{sd}=0.99)$, respectively. Ages ranged from 18 to 25 years, with the mean age of participants $21.44(\mathrm{sd}=1.58)$. The mean weekly income was between NZD 100 and $299(\mathrm{sd}=0.98)$.

\subsection{Factors That Predict Online Impulse Buying Tendency}

Multiple linear regression showed the results of $R^{2}=0.375, p<0.05$. This means that BNPL use, credit card use, overdraft account use, average weekly income and conversion sensitivity score account for $37.5 \%$ of the variance in OIBT scores, as shown in Table 3. BNPL use $(\beta=0.7133)$, overdraft account use $(\beta=0.181)$ and conversion sensitivity score $(\beta=0.502)$ were found to significantly predict OIBT score, supporting $\mathrm{H} 1$ and $\mathrm{H} 2$.

Table 3. Summary table of multiple regression analysis for predicting online impulse buying tendency (OIBT) score.

\begin{tabular}{cccccc}
\hline Model sig. & Adjusted $\mathbf{R}^{2}$ & $\begin{array}{c}\text { Dependent } \\
\text { Variable }\end{array}$ & Independent Variable & $\begin{array}{c}\text { Standardised } \\
\text { Coefficients }(\beta)\end{array}$ & Sig. $(\beta)$ \\
\hline & & BNPL user & 0.1733 & $0.040^{* *}$ \\
0.000 & \multirow{2}{*}{0.375} & OIBT score & Credit card user * & -0.084 & 0.287 \\
& & Overdraft account user & 0.181 & $0.030^{* *}$ \\
& & Average weekly income & -0.043 & 0.644 \\
& & Conversion tool & 0.502 & $0.000^{* *}$ \\
& & sensitivity score & & \\
\hline
\end{tabular}

* Dummy variables used for analysis ** Statistically significant result, $p<0.5$.

\subsection{BNPL Use}

Of the 109 survey respondents, 33 (30.3\%) reported having used a BNPL service. Of those BNPL users, $78.8 \%$ reported having made an online purchase that they would not have made if BNPL had not been available $(n=26)$. The relationship between intention toward BNPL-enabled online purchases and BNPL use was statistically significant (chi-square with one degree of freedom $=74.108, p=0.00$ ), supporting $\mathrm{H} 3$.

Hypotheses $\mathrm{H} 2 \mathrm{a}$ and $\mathrm{H} 2 \mathrm{~b}$ were supported. It was found that BNPL users had significantly higher OITB scores $(m=4.17)$ than non-users $(m=3.60), t(107)=2.934, p=0.004$. This was also true of BNPL users' cognitive-IBT scores $(m=3.83)$ and affective-IBT scores $(m=4.64)$ compared to non-users ( $m=3.16$ and $m=4.20$, respectively), $t(107)=2.981, p=0.004$ and $t(107)=2.153, p=0.034$, respectively. The difference in average weekly income for BNPL users and non-users was not statistically significant, $t(107)=1.425, p=0.157$. No significant association was found between BNPL use and credit card ownership $(p=0.129)$. There was no significant difference in OIBT scores between credit card owners and those who did not own a credit card, $t(107)=0.218, p=0.828$. However, respondents with an overdraft bank account had significantly higher OIBT scores $(m=4.24)$ compared to those without $(m=3.64), t(107)=2.737, p=0.007$. 


\subsection{Conversion Tool Sensitivity}

OIBT score was positively correlated with the conversion tool sensitivity score $(r=0.544, p=0.00)$. The most effective conversion tool was the live countdown timer $(m=3.477)$, followed by, in order, the " 1 item left" indicator $(m=3.431)$, free shipping $(m=3.266)$, "low in stock" indicator $(m=3.018)$, free returns $(m=2.89)$, follow-up discount offer email $(m=2.816)$, and follow-up cart reminder email $(m=2.018)$. Correlations were observed between OITB and the following six conversion tools (in order of correlation strength): " 1 item left" indicator $(r=0.479)$, live countdown timer $(r=0.458)$, "low stock" indicator $(r=0.417)$, follow-up cart reminder email $(r=0.384)$, follow-up discount email $(r=0.343)$, and free shipping $(r=0.338)$. Free returns were not strongly correlated with OITB score $(r=0.188)$ (refer Table 4 for summary analysis).

Table 4. Summary table of multiple regression analysis for conversion sensitivity score.

\begin{tabular}{cccccc}
\hline Model sig. & Adjusted $\mathbf{R}^{2}$ & $\begin{array}{c}\text { Dependent } \\
\text { Variable }\end{array}$ & Independent Variable & $\begin{array}{c}\text { Standardised } \\
\text { Coefficients }(\boldsymbol{\beta})\end{array}$ & Sig. ( $\beta$ ) \\
\hline \multirow{7}{*}{0.000} & 0.282 & $\begin{array}{c}\text { Conversion } \\
\text { sensitivity score }\end{array}$ & $\begin{array}{c}\text { Average weekly income } \\
\text { OIBT score }\end{array}$ & -0.011 & 0.894 \\
\hline \multicolumn{7}{c}{ * Statistically significant result, $p<0.5}$. & $0.000^{* *}$ \\
\hline \multicolumn{7}{c}{}
\end{tabular}

Average weekly income and OIBT score accounted for $28.2 \%$ of the variance in conversion sensitivity scores. When average weekly income was held constant (as a covariate), OIBT score ( $\beta=-0.544)$ was found to significantly predict the conversion tool sensitivity score, supporting H1.

\section{Discussion and Conclusions}

In an effort to better understand the antecedents of overconsumption among one group of consumers, young adult females, this study explored online purchasing behaviour through the lens of impulsivity. Following calls for more studies that merge psychological factors with external stimuli in understanding impulsivity [36], as well as calls for examination of individual, context-specific marketing stimuli in promoting impulsiveness [34], this study modified the impulse buying tendency scale by Verplanken and Herabadi [20], making it applicable to the online context of shopping behaviour. The resulting online impulse buying tendency scale successfully replicated the psychometric structure of cognitive and affective factors underlying the trait, as in the original study. The results of this study indicate that there is a close relationship between the impulse purchasing behaviour of young adult females, and their use of BNPL credit platforms. BNPL users in this study reported higher levels of online impulsivity, and increased likelihood of future purchases if BNPL platforms were available to them.

The theoretical implications of this demonstrate that these underlying attitudinal and behavioural variables are not only associated with the brick-and-mortar store context. These same internal tendencies are implicated in both the online and offline environment, suggesting that impulse buying tendency is not significantly context-dependent. By building upon a well-recognised study in impulse buying research, this provides a reliable, preliminary basis for a measurement scale specific to online impulsivity - something that the original scale and its subsequent replications did not allow.

In the present study, users of BNPL schemes totalled only $30 \%$ of the sample population, however BNPL platforms are still in their infancy in many categories of consumer retail (such as apparel), and it is proposed that, as the practise becomes more embedded socially, these programmes may overtake traditional credit within the consumer retail setting. Where this study highlighted the availability of the BNPL tool in stimulating impulsive purchases, and in promoting intention toward future purchases, the findings are important in better understanding the attitude-behaviour gap apparent in retail purchase behaviour amongst the sampled group of consumers. Most young adults, like other consumers, are well educated regarding sustainability principles and their relationship to consumption behaviour [2]. The lifestyle of young adult consumers, however, shows evidence of behavioural intention discrepancy in this regard [13]. To further the findings demonstrated in this 
study, it would be beneficial to observe the relationship between online impulse buying tendency and the actual frequency of impulsive online purchases. Future research should consider implementing the survey concurrently with either a self-report method by the participant, or an observation method that monitors the participant's online activity for greater accuracy.

Growing materialism, combined with socially driven consumption behaviours, has meant that almost all retail categories show evidence of overconsumption [17]. Where a consumer's lack of self-control in purchasing is cited as a promoting mechanism for overconsumption, e.g., [4], the availability of tools that directly act on a consumer's propensity toward impulsive purchasing should be viewed critically within a sustainable retail framework. Logic would suggest that the interest-free nature of BNPL instalments, the ease of use of the platforms, and the ability to buy more at one time by splitting up payments, are considered beneficial by users. Promoting BNPL platforms as merely "your money, used on your schedule" [57] reconceptualises credit and reduces the association with traditional forms of consumer debt. When finance platforms such as this are combined with purchase stimulating conversion tools such as " 1 item left" or "low stock" indicators, the purchase setting becomes even more likely to facilitate overconsumption of products.

While past literature stresses the constraint of situational variables such as money available and discretionary income [41], the present study demonstrated that online impulsive consumption is independent of one's financial situation. One of the most interesting findings of this study was the absence of a relationship between level of income and online impulse buying tendency. The influence of internal variables (individual cognitive and affective traits relating to impulsive consumption) are seemingly unhindered by the availability of personal resources in this setting. This leads to the question of whether the impact of discretionary income has been moderated by the availability of easy access credit in such a way as to change the nature of the retail setting overall?

Overarchingly, the current study serves to confirm one relatively recent sales tool (BNPL programmes) as a driver of increased impulse purchasing in the online retail setting. The study also increases our understanding of the set of antecedents to overconsumption in this setting, as related to individual impulsivity. These are important findings in the context of planning for sustainability in retail environments, where consumer benefit of such tools must be balanced with the potential for consumption-related harm-both to the individual and to the world.

\section{Limitations}

This study was limited to a sample of females, aged between 18 and 25 years. As noted in prior studies of impulsivity, the trait is moderated by age and gender [12,46]. Future research should document the changing attitudes and usage patterns of BNPL users as the platforms become increasingly normalised, as well as the insights of other groups of consumers outside this particular segment. From a methodological perspective, additional validation and modification of the online impulse buying tendency (OIBT) scale is recommended to ensure it is a reliable instrument. For this, a larger sample of survey respondents would increase generalisability and accuracy of results. Additionally, items of the scale could be further modified to ensure that each item implicates only one internal factor, cognitive or affective, rather than a statement that connotes both. The movement towards omnichannel shopping experiences signifies a need to see exactly where the online and offline behaviours intersect. A possible future study could implement the original IBT scale alongside the modified OIBT scale, to see if respondents tend to be more impulsive online or offline.

Author Contributions: Conceptualisation, L.M.; Data curation, L.A.F.; Formal analysis, L.A.F.; Investigation, L.A.F.; Methodology, L.A.F. and L.M.; Validation, L.A.F.; Visualisation, L.M.; Writing-original draft, L.M.; Writing-review and editing, L.M. All authors have read and agreed to the published version of the manuscript.

Funding: This research received no external funding.

Conflicts of Interest: The authors declare no conflict of interest. 


\section{Appendix A. Factor Loadings}

\begin{tabular}{|l|c|c|}
\hline \multicolumn{2}{|c|}{ Pattern Matrix } \\
\end{tabular}

Figure A1. Cont. 


\begin{tabular}{|l|l|l|}
\hline $\begin{array}{l}\text { Q18 If I see something } \\
\text { new on a website, I want } \\
\text { to buy it }\end{array}$ & 0.459 & 0.192 \\
\hline $\begin{array}{l}\text { Q07 ** like to compare } \\
\text { different brands before I } \\
\text { make an online purchase }\end{array}$ & 0.436 & -0.211 \\
\hline $\begin{array}{l}\text { Q05**I only buy things } \\
\text { online that I really need }\end{array}$ & 0.436 & 0.328 \\
\hline $\begin{array}{l}\text { Q17 I find it difficult to } \\
\text { pass up a good online } \\
\text { deal }\end{array}$ & -0.027 & 0.817 \\
\hline $\begin{array}{l}\text { Q13 I sometimes feel } \\
\text { guilty after having bought } \\
\text { something online }\end{array}$ & -0.055 & 0.660 \\
\hline $\begin{array}{l}\text { Q16 I always see } \\
\text { something I want when I } \\
\text { browse online stores }\end{array}$ & -0.169 & 0.584 \\
\hline $\begin{array}{l}\text { Q20 I sometimes make } \\
\text { an online order because I } \\
\text { like buying things, rather } \\
\text { than because I need } \\
\text { them }\end{array}$ & -0.376 & 0.511 \\
\hline $\begin{array}{l}\text { Q02 **I usually only buy } \\
\text { things that I initially } \\
\text { intended to buy from a } \\
\text { website }\end{array}$ & 0.106 & 0.476 \\
\hline $\begin{array}{l}\text { Q15 I can become very } \\
\text { excited if I see something } \\
\text { is available online that I } \\
\text { would like to buy }\end{array}$ & 0.132 & 0.475 \\
\hline $\begin{array}{l}\text { Q06 **It is not my style to } \\
\text { just buy things online }\end{array}$ & 0.250 & 0.464 \\
\hline $\begin{array}{l}\text { Q11 It is a struggle to } \\
\text { leave nice items in my } \\
\text { cart when I am browsing } \\
\text { online }\end{array}$ & 0.342 & 0.440 \\
\hline & & \\
\hline
\end{tabular}

Figure A1. Factor Loadings.

\section{References}

1. Cherry, C.; Scott, K.; Barrett, J.; Pidgeon, N. Public acceptance of resource-efficiency strategies to mitigate climate change. Nat. Clim. Chang. 2018, 8, 1007-1012. [CrossRef]

2. Jung, H.J.; Choi, Y.J.; Oh, K.W. Influencing factors of Chinese consumers' purchase intention to sustainable apparel products: Exploring consumer “attitude-behavioral intention" gap. Sustainability 2020, 12, 1770. [CrossRef]

3. Allwood, J.M.; Ashby, M.F.; Gutowski, T.G.; Worrell, E. Material efficiency: Providing material services with less material production. Philos. Trans. R. Soc. 2013, 371. [CrossRef] [PubMed]

4. Helm, S.; Subramaniam, B. Exploring socio-cognitive mindfulness in the context of sustainable consumption. Sustainability 2019, 11, 3692. [CrossRef]

5. Pereira Heath, M.T.; Chatzidakis, A. 'Blame it on marketing': Consumers' views on unsustainable consumption. Int. J. Consum. Stud. 2012, 36, 656-667. [CrossRef] 
6. Håkansson, A. What is overconsumption?-A step towards a common understanding. Int. J. Consum. Stud. 2014, 38, 692-700. [CrossRef]

7. Hausman, A. A multi-method investigation of consumer motivations in impulse buying behavior. J. Consum. Mark. 2000, 17, 403-426. [CrossRef]

8. Liu, Y.; Li, H.; Hu, F. Website attributes in urging online impulse purchase: An empirical investigation on consumer perceptions. Decis. Support Syst. 2013, 55, 829-837. [CrossRef]

9. Verhagen, T.; van Dolen, W. The influence of online store beliefs on consumer online impulse buying: A model and empirical application. Inf. Manag. 2011, 48, 320-327. [CrossRef]

10. O’Brien, S. Consumers Cough up $\$ 5400$ a Year on Impulse Purchases. 2018. Available online: CNBC.com (accessed on 23 February 2019).

11. Badgaiyan, A.J.; Verma, A.; Dixit, S. Impulsive buying tendency: Measuring important relationships with a new perspective and an indigenous scale. IIMB Manag. Rev. 2016, 28, 186-199. [CrossRef]

12. Rook, D.W. The buying impulse. J. Consum. Res. 1987, 14, 189-199. [CrossRef]

13. Carrington, M.; Neville, B.; Whitwell, G. Lost in translation: Exploring the ethical consumer intention-behavior gap. J. Bus. Res. 2014, 67, 2759-2767. [CrossRef]

14. Vermeir, I.; Verbeke, W. Sustainable food consumption: Exploring the consumer "attitude-behavioral intention" gap. J. Agric. Environ. Ethics. 2006, 19, 169-194. [CrossRef]

15. Tanner, C.; Kast, S.W. Promoting sustainable consumption: Determinants of green purchases by Swiss consumers. Psychol. Mark. 2003, 20, 883-902. [CrossRef]

16. Thorman, D.; Whitmarsh, L.; Demski, C. Policy acceptance of low-consumption governance approaches: The effect of social norms and hypocrisy. Sustainability 2020, 12, 1247. [CrossRef]

17. Winter, D. Shopping for sustainability: Psychological solutions to overconsumption. In Psychology and Consumer Culture: The Struggle for a Good Life in a Materialistic World; Kasser, T., Kanner, A.D., Eds.; American Psychological Association: Washington, DC, USA, 2004; pp. 69-87.

18. Thompson, E.R.; Prendergast, G.P. The influence of trait affect and the five-factor personality model on impulse buying. Pers. Individ. Differ. 2015, 76, 216-221. [CrossRef]

19. Abraham, J.; Dameyasani, A.W. Impulsive buying, cultural values dimensions, and symbolic meaning of money: A study on college students in Indonesia's capital city and its surrounding. Int. J. Res. Stud. Psychol. 2013, 2, 35-52.

20. Verplanken, B.; Herabadi, A. Individual differences in impulse buying tendency: Feeling and no thinking. Eur. J. Personal. 2001, 15, S71-S83. [CrossRef]

21. Rose, P. Mediators of the association between narcissism and compulsive buying: The roles of materialism and impulse control. Psychol. Addict. Behav. 2007, 21, 576. [CrossRef]

22. Chan, T.K.; Cheung, C.M.; Lee, Z.W. The state of online impulse-buying research: A literature analysis. Inf. Manag. 2017, 54, 204-217. [CrossRef]

23. Chung, S.; Kramer, T.; Wong, E.M. Do touch interface users feel more engaged? The impact of input device type on online shoppers' engagement, affect, and purchase decisions. Psychol. Mark. 2018, 35, 795-806. [CrossRef]

24. Ono, A.; Nakamura, A.; Okuno, A.; Sumikawa, M. Consumer motivations in browsing online stores with mobile devices. Int. J. Electron. Commer. 2012, 16, 153-178.

25. Gañac, C.G. Investigating consumer optimum stimulation level and exploratory online buying behavior. DLSU Bus. Econ. Rev. 2018, 28, 67-85.

26. Park, J.; Hill, W.T. Exploring the role of justification and cognitive effort exertion on post-purchase regret in online shopping. Comput. Hum. Behav. 2018, 83, 235-242. [CrossRef]

27. Park, E.J.; Kim, E.Y.; Funches, V.M.; Foxx, W. Apparel product attributes, web browsing, and e-impulse buying on shopping websites. J. Bus. Res. 2012, 65, 1583-1589. [CrossRef]

28. Clemons, E.K.; Wilson, J.; Matt, C.; Hess, T.; Ren, F.; Jin, F.; Koh, N.S. Global differences in online shopping behavior: Understanding factors leading to trust. J. Manag. Inf. Syst. 2016, 33, 1117-1148. [CrossRef]

29. Thaichon, P.; Surachartkumtonkun, J.; Quach, S.; Weaven, S.; Palmatier, R.W. Hybrid sales structures in the age of e-commerce. J. Pers. Sell. Sales Manag. 2018, 38, 277-302. [CrossRef]

30. Jones, M.A.; Reynolds, K.E.; Mothersbaugh, D.L.; Beatty, S.E. The positive and negative effects of switching costs on relational outcomes. J. Serv. Res. 2007, 9, 335-355. [CrossRef] 
31. Flight, R.L.; Rountree, M.M.; Beatty, S.E. Feeling the urge: Affect in impulsive and compulsive buying. J. Mark. Theory Pract. 2012, 20, 453-466. [CrossRef]

32. Punj, G. Impulse buying and variety seeking: Similarities and differences. J. Bus. Res. 2011, 64, 745-748. [CrossRef]

33. Baumeister, R.F. Yielding to temptation: Self-control failure, impulsive purchasing, and consumer behavior. J. Consum. Res. 2002, 28, 670-676. [CrossRef]

34. Iyer, G.R.; Blut, M.; Xiao, S.H.; Grewal, D. Impulse buying: A meta-analytic review. J. Acad. Mark. Sci. 2020, 48, 384-404. [CrossRef]

35. Mattila, A.S.; Wirtz, J. Congruency of scent and music as a driver of in-store evaluations and behavior. J. Retail. 2001, 77, 272-289. [CrossRef]

36. Vohs, K.D.; Faber, R.J. Spent resources: Self-regulatory resource availability affects impulse buying. J. Consum. Res. 2007, 33, 537-547. [CrossRef]

37. Dhar, R.; Wertenbroch, K. Consumer choice between hedonic and utilitarian goods. J. Mark. Res. 2000, 37, 60-71. [CrossRef]

38. Montgomery, A.; Li, S.; Srinivasan, K.; Liechty, J. Using Web Path Analysis. Researchgate 2002. Available online: https://www.researchgate.net/publication/277290686_Using_Web_Path_Analysis (accessed on 5 September 2020).

39. Wu, L.; Chen, K.W.; Chiu, M.L. Defining key drivers of online impulse purchasing: A perspective of both impulse shoppers and system users. Int. J. Inf. Manag. 2016, 36, 284-296. [CrossRef]

40. Madhavaram, S.R.; Laverie, D.A. Exploring impulse purchasing on the internet. ACR N. Am. Adv. 2004, 31, 59-66.

41. Beatty, S.E.; Ferrell, M.E. Impulse buying: Modeling its precursors. J. Retail. 1998, 74, 169-191. [CrossRef]

42. Badgaiyan, A.J.; Verma, A. Does urge to buy impulsively differ from impulsive buying behaviour? Assessing the impact of situational factors. J. Retail. Consum. Serv. 2015, 22, 145-157. [CrossRef]

43. Stern, H. The significance of impulse buying today. J. Mark. 1962, 26, 59-62. [CrossRef]

44. Coley, A.; Burgess, B. Gender differences in cognitive and affective impulse buying. J. Fash. Mark. Manag. Int. J. 2003, 7, 282-295. [CrossRef]

45. Rook, D.; Fisher, R. Normative influences on impulsive buying behavior. J. Consum. Res. 1995, 22, $305-313$. [CrossRef]

46. Dittmar, H.; Long, K.; Meek, R. Buying on the internet: Gender differences in online and conventional buying motivations. Sex Roles 2004, 50, 423-444. [CrossRef]

47. Chamorro-Premuzic, T. The Psychology of Impulsive Shopping, The Guardian. Available online: https://www.theguardian.com/media-network/2015/nov/26/psychology-impulsive-shopping-christmasblack-friday-sales (accessed on 26 November 2019).

48. Childers, T.L.; Carr, C.L.; Peck, J.; Carsoni, S. Hedonic and utilitarian motivations for online retail shopping behavior. J. Retail. 2001, 77, 511-535. [CrossRef]

49. Akram, U.; Hui, P.; Khan, M.; Tanveer, Y.; Mehmood, K.; Ahmad, W. How website quality affects online impulse buying: Moderating effects of sales promotion and credit card use. Asia Pac. J. Mark. Logist. 2017, 30, 235-256. [CrossRef]

50. Roberts, J.A.; Jones, E. Money attitudes, credit card use, and compulsive buying among American college students. J. Consum. Aff. 2001, 35, 213-240. [CrossRef]

51. Lachance, M.J. Young adults' attitudes towards credit. Int. J. Consum. Stud. 2012, 36, 539-548. [CrossRef]

52. Soman, D.; Gourville, J.T. Transaction decoupling: How price bundling affects the decision to consume. J. Mark. Res. 2001, 38, 30-44. [CrossRef]

53. Karbasivar, A.; Yarahmadi, H. Evaluating effective factors on consumer impulse buying behavior. Asian J. Bus. Manag. Stud. 2011, 2, 174-181.

54. Erasmus, A.C.; Mathunjwa, G.Q. Idiosyncratic use of credit facilities by consumers in an emerging economy. Int. J. Consum. Stud. 2011, 35, 359-371. [CrossRef]

55. Houle, J.N. A generation indebted: Young adult debt across three cohorts. Soc. Probl. 2014, 61, 448-465.

56. Edmunds, S. Generation Now Drives Buy-Now-Pay-Later Schemes, Stuff. 2018. Available online: https: //www.stuff.co.nz/business/109412973/finance-companies-tackle-growth-of-buynowpaylater-schemes (accessed on 18 December 2019). 
57. Edmunds, S. Here's How Part-Payment Platforms Turn Nasty, Stuff. 2018. Available online: https://www.stuff. co.nz/business/108793316/heres-how-partpayment-platforms-turn-nasty (accessed on 23 November 2019).

58. McGowan, M. Afterpay: Buy-now-pay-later scheme soars in popularity but experts sound warning. The Guardian, 21 September 2017.

59. McNeill, L.S. The place of debt in establishing identity and self-worth in transitional life phases: Young home leavers and credit. Int. J. Consum. Stud. 2014, 38, 69-74. [CrossRef]

60. Penman, S.; McNeill, L.S. Spending their way to adulthood: Consumption outside the nest. Young Consum. 2008, 9, 155-169. [CrossRef]

61. Dittmar, H.; Beattie, J.; Friese, S. Gender identity and material symbols: Objects and decision considerations in impulse purchases. J. Eco. Psych. 1995, 16, 491-511. [CrossRef]

62. Skallerud, K.; Korneliussen, T.; Olsen, S.O. An examination of consumers' cross-shopping behaviour. J. Retail. Consum. Serv. 2009, 16, 181-189. [CrossRef]

63. Hoyle, R. Statistical Strategies for Small Sample Research; Sage: Addison, TX, USA, 1999.

64. Marsh, H.W.; Hau, K.T. Confirmatory Factor Analysis: Strategies for Small Sample Sizes-Statistical Strategies for Small Sample Research; Sage: Austin, TX, USA, 1999.

65. Boomsma, A.; Hoogland, J.J. The Robustness of LISREL Modeling Revisited: Present and Future a Festschrift in Honor of Karl Jöreskog. 2001. Available online: aboomsma.webhosting.rug.nl (accessed on 5 August 2020).

66. Kline, R.B. Principles and Practice of Structural Equation Modeling, 2nd ed.; The Guilford Press: Guilford, NY, USA, 2005.

67. Muthén, L.K.; Muthén, B.O. How to Use a Monte Carlo Study to Decide on Sample Size and Determine Power. Struct. Equ. Modeling A Multidiscip. J. 2002, 9, 599-620.

68. Gerbing, D.W.; Anderson, J.C. Monte carlo evaluations of goodness of fit indices for structural equation models. Sociol. Methods Res. 1992, 21, 132-160. [CrossRef]

69. Wuensch, K.L. Comparing Two Groups' Factor Structures: Pearson r and the Coefficient of Congruence. 2016. Available online: http://core.ecu.edu/psyc/wuenschk/MV/FA/FactorStructure-TwoGroups.docx (accessed on 5 August 2020).

(C) 2020 by the authors. Licensee MDPI, Basel, Switzerland. This article is an open access article distributed under the terms and conditions of the Creative Commons Attribution (CC BY) license (http://creativecommons.org/licenses/by/4.0/). 